\title{
Levels of Lead, Cadmium and Chromium in Oreochromis Niloticus in Lagos State Lagoon 1Ademola-Aremu, 0.0., ${ }^{2}$ Aina, 0.M. and ${ }^{1}$ Adetiloye, A.0.
}

\begin{abstract}
Lead ( $\mathrm{Pb}$ ), Cadmium (Cd) and Chromium (Cr) levels in Oreochromis niloticus, aquatic plants, water and sawdust were collected and analyzed for Lead, Cadmium and Chromium using atomic absorption spectroscopy. Results obtained showed that sawdust had the highest Lead and Chromium contents of $32.0 \pm 0.99 \mu \mathrm{g} / \mathrm{g}$ and $54.7 \pm$ $55.65 \mu \mathrm{g} / \mathrm{g}$ respectively. Aquatic plant had the highest concentration of Cadmium $37.0 \mu \mathrm{g} / \mathrm{g} \pm 3.96 \mu \mathrm{g} / \mathrm{g}$. The differences between the levels of Lead and Cadmium in sawdust and fish were statistically significant while there was no significant difference in the level of Chromium between sawdust and fish. The difference in Cadmium and Chromium between plant and fish were also statistically significant. All statistical analysis was carried out at 95\% confidence limit $(P<0.05)$ using student $t$-test. From these results, it was deduced that sawmilling, log transportation and domestic waste disposal into the lagoon may have been responsible for these high metal levels.
\end{abstract}

\section{Introduction}

Qin many aquatic ecosystems due to anthropogenic activities, and it is often stated that aquatic sediments constitute the most important reservoir or sink of metals and pollutants (Burken and Schnoor,1996).

The incidences of heavy metal pollution of coastal waters by anthropogenic inputs are nowadays not uncommon in almost all less developed countries. Nigeria being a less industrialized nation in the West Coast of Africa is presently experiencing impacts of environmental degradation probably with the same magnitude both on land and within her exclusive economic zone.

The bank of Lagos Lagoon at EbuteMeta, South West Nigeria is home to numerous sawmills. This is because logs harvested from the forests in other riverine states in Nigeria including Edo, Ogun, Ondo and Ekiti are easily transported to this area by floating or rafting in rivers, creeks and lagoons with the aid of tug boats. The lagoons are being used to store the logs before they are sawn. The logs, also scattered along the bank of the lagoon contribute to the darkening of the waters.

Heavy metals contamination affects the biosphere in many places worldwide (Cunnigham, et al., 1996; Sheppard et al, 1975). Excess concentrations of some heavy metals in soil such as $\mathrm{Cd}$ (II), $\mathrm{Cr}$ (VI) and $\mathrm{Pb}$ (II) have caused the disruption in natural aquatic and terrestrial ecosystems.

Apart from those communities around the lagoon exposed to high levels of pollution ${ }^{1}$ Department of Environmental Management and Toxicology,.2Department of Forestry and Wildife Management,University of Agriculture, Abeokuta,Nigeria by industrial effluents or emissions rich in heavy metals, it is evident that, for most individuals, food and diet are the most important sources for these potentially toxic elements. Thus, Chester (1982) modeling the routes of human exposure to the heavy metals presented data illustrating that the proportion of heavy metals intake normally accounted for by the content of elements in food and drinking water amounts to approximately $80 \%$ for cadmium, $40 \%$ for lead and $98 \%$ for mercury.

The Value of Fish as Food

Fish is a major source of animal protein to a large number of Nigerians, particularly in the Lagos environs. Fish contains a high level of protein (17 - 20\%) with an amino-acid profile similar to that of meat in ruminants and fowl. Fish is less tough and more digestible compared to beef, mutton, chicken and bush meat. Due to its greater digestibility, fish is usually recommended to patients with digestion disorder such as ulcers. Aquatic animals are a source of minerals, such as calcium, iron and phosphorus as well as trace vitamins. Marine species are particularly rich in iodine. Fish is abundant and to some extent occurs free in nature. Thus, this may account for its relatively low cost compared to other types of meat. There is hardly any religious taboo against the consumption of fish unlike pork and beef. Fish contains more water, waste matter and high $\mathrm{pH}$ (Ndiakwere, 1984). The fatty acid content in fish is polyunsaturated fats and particularly in those which are attributed to reduce blood cholesterol. 


\section{Lead}

A non-essential element; it is a neurotoxin and a good example of a multimedia pollutant. Lead is very soft $(<35$ diamond pyramid hardness) and dense $\left(11.34 \mathrm{~g} / \mathrm{cm}^{3}\right)$ and occurs as an important constituent of more than 200 minerals. Lead is one of the easiest metals to mine. This is a denser silver metal which is soft and malleable and is easily cast, moulded and extruded. Lead is found in many parts of the world as galena, but mixed with other ores such as fluorspar. Lead has a long residence time compared with most other pollutants due to their low solubility and relative freedom from microbes accessible to the food chain and to human metabolism (Chester, 1982).

The properties of lead have been exploited by man for making lead toxicity which is known to be due to enzyme inhibition and lead appears to act at a large number of biochemical sites (Sheppard et al., 1975). Lead poison is accompanied by proteinurea which is the morphological manifestation of an increased degradation of proteinaceous material. The significant poisoning affect of $\mathrm{Pb}$ in medicine is its effect on the central nervous system.

\section{Cadmium}

Cadmium is a highly toxic nonessential metal, which accumulates in the kidneys of mammals and can cause kidney disfunction. In humans, kidney damage diagnosed by the presence of micro-globulin proteins is the major toxic effect resulting from chronic exposure to the metal. Cadmium has a tendency of accumulating in human organs (a half-life of 30 years). The International Agency for Research on Cancer (IARC) classified cadmium with those chemicals that are probably carcinogenic to man. The general population is exposed to cadmium via food, air and water. It has been shown that food is a major source of cadmium intake as well as tobacco smoking and occasional exposures to fumes.

\section{Chromium}

A micronutrient which is essential for carbohydrate metabolism in animals. Pollution of soils occurs as a result of the dumping of chromate wastes, such as those from tanneries, electroplating, manufacturing industries and textile industries. However, unlike many other heavy metals, chromium can exist in a trivalent (Chromate) and a hexavalent form (Chromate) and the $\mathrm{Cr}$ (VI) form is more phytotoxic than the $\mathrm{Cr}$ (III) form. Chromium is carcinogenic, causing cancer in chromate workers chronically exposed to $\mathrm{Cr}$ - containing dusts.

\section{An Introduction to Tilapia Fish}

Tilapia fish belong to the family Cichlids; they are widely distributed in the tropical and sub-tropical part of South and Central America and Africa. They are almost exclusively fresh water inhabitants with the exception of the species of Tilapia galiea (Oreochromis galiea) and Tilapia zilli (Oreochromis zillus) which have adapted to brackish water.

Tilapias have several attributes which makes them attractive as culture species: high tolerance of poor water quality, crowding, good performance on commercial catfish feed (32\% protein), a high degree of disease resistance, and a mild flavoured, white flesh. Due to their tolerance to crowding and poor water quality, Tilapias are well suited to cage culture and re-circulating systems.

Research has also shown that in addition to controlling filamentous algae, tilapia stocked in channel catfish ponds can help control off-flavours by eating blue-green and other large planktonic algae. Tilapias have a good growth rate and their performance is best in a temperature range of $72-90^{\circ} \mathrm{F}$. Tilapia cichlids are found in rivers as well as standing water (Raskin et al., 1997).

\section{Sawmilling Industry in Nigeria}

Sawmilling is the process of converting logs into lumbers by using a variety of machines such as (i) band saws capable of breaking down large logs into desired sizes and (ii) re-sawmilling machines for processing the cants and flitches into specified and marketable dimensions (Aina et al. 2006). The earliest form of timber conversion in Nigeria was pit sawing which were believed to have been established about 1782 by the Portuguese, while the first power-driven sawmill was installed at the beginning of the $20^{\text {th }}$ Century. Since then the sawmilling industry has become fully established in the country (Okigbo, 1964; NISER, 1972; Lucas, 1975).

\section{Materials and Methods}

\section{Samples}

- Sawdust, Water, Plant (Ducksalad), Plant (Ducksalad), Fish (Oreochromis niloticus). 


\section{Materials}

- Mettle Toledo balance, Electric stove, Kitchen blender, Filter paper, Hand groves, Nose mask, Tissue paper, Paper tape, Tongs.

Glass wares

- $50 \mathrm{ml}$ conical flasks, $50 \mathrm{ml}$ measuring cylinders, $100 \mathrm{ml}$ beakers, $250 \mathrm{ml}$ conical flasks.

Reagents

Analar grade reagents were used:

- Conc. $\mathrm{H}_{2} \mathrm{SO}_{4}$, Conc. trioxonitrate (v) acid $\left(\mathrm{HNO}_{3}\right)$, Conc. $\mathrm{HCl}$, Conc. $\mathrm{NH}_{4} \mathrm{OH}, 30 \%$ $\mathrm{H}_{2} \mathrm{O}_{2}$, Perchloric acid.

\section{Reagent Preparation $\left(30 \% \mathbf{H}_{2} \mathbf{O}_{2}\right)$}

$30 \mathrm{ml}$ of $\mathrm{H}_{2} \mathrm{O}_{2}$ was measured into a conical flask and added to $70 \mathrm{ml}$ distilled water.

\section{Sampling}

The fish, water and plant samples were collected from the lagoon while the sawdust samples were collected from the sawmill industries around the lagoon.

\section{Collection of Fish}

The fish samples were collected from the Lagos lagoon at Ebute-meta at different points with a distance of 10 meters apart. A composite sampling was made.

The fish samples were killed and rinsed with distilled water and oven-dried for 2 hours at $105^{\circ} \mathrm{C}$. After drying, the fish mussels were shredded, blended, and packaged in a small transparent polythene bag.

\section{Collection of Sawdust Samples}

The sawdust samples were collected at different points from the sawmill industries besides the lagoon using a spoon. The collected samples were oven-dried at $100^{\circ} \mathrm{C}$ for 24 hours and packaged in a polythene bag.

\section{Collection of Water Samples}

Water samples were taken from the Lagos lagoon at 6 different points with metal free plastic bottles. The plastic bottles were first rinsed with the water from the lagoon. The plastic bottles were filled to the brim.

\section{Collection of Plant Samples}

The plant samples of Paspalium conjugatum (Sourgrass) and Heteranther califolia (Ducksalad) were collected from different points from the lagoon and rinsed with distilled water to remove dirt. The plant samples were oven dried at $60^{\circ} \mathrm{C}$ for 24 hours. The dried plant samples were ground with mortal and pestle and then packed in small transparent polythene bags.

\section{Digestion of Fish Sample}

The $\mathrm{HNO}_{3}-\mathrm{H}_{2} \mathrm{SO}_{4}$ wet digestion method was used for the decomposition of the organic matters present in the fish samples.

\section{Procedure}

- $1.50 \mathrm{~g}$ of the fish mussels was weighed into a $50 \mathrm{ml}$ conical flask.

- $5 \mathrm{ml}$ of conc. $\mathrm{HNO}_{3}$ was added to the sample.

- $5 \mathrm{ml}$ of conc. $\mathrm{H}_{2} \mathrm{SO}_{4}$ was also added to the sample.

- The sample mixture was then heated on a heating mantle at a temperature slightly above $100^{\circ} \mathrm{C}$.

- $5 \mathrm{ml}$ of conc. $\mathrm{HNO}_{3}$ was added and heated for $2 \mathrm{~min}$.

- $5 \mathrm{ml}$ of conc. $\mathrm{HNO}_{3}$ was added again and heated until the nitrogen oxide fumes were given off and a clear solution was obtained.

- The clear solution was allowed to cool and filtered into a measuring cylinder and made up to $50 \mathrm{ml}$ with distilled water.

- The diluted solution was then transferred into a sample bottle and labelled.

\section{Digestion of Water Sample}

Wet-ashing digestion was adopted with concentrated $\mathrm{HNO}_{3}$.

\section{Procedure}

- $100 \mathrm{ml}$ of the water sample was measured into $250 \mathrm{ml}$ conical flask.

- $2 \mathrm{ml}$ of conc. $\mathrm{HNO}_{3}$ was added to acidify the water sample.

- The sample solution was evaporated to dryness on a steam bath and allowed to cool.

- $25 \mathrm{ml}$ of conc. $\mathrm{HNO}_{3}$ was added to the residue and heated to boil on a hot plate to evaporate to a small volume.

- $25 \mathrm{ml}$ of conc. $\mathrm{HNO}_{3}$ was added again followed by $5 \mathrm{ml} \mathrm{H}_{2} \mathrm{O}_{2}$

- The sample solution was heated until the presence of a white residue in the flask was noticed and the ashing was completed.

- Little quantities of warm distilled water was added to the ash obtained followed by $1 \mathrm{ml} \mathrm{HCl}$ to dissolved the ash.

- The resultant solution was allowed cool and filtered into a volumetric flask using a whatman paper No. 42.

- $2 \mathrm{ml}$ of $\mathrm{NH}_{4} \mathrm{OH}$ was added to the solution so as to neutralized the solution. 
- Finally, the solution was made up to the mark with distilled water and transferred into a $100 \mathrm{ml}$ sample bottle.

\section{Digestion of Plant Sample}

Wet digestion by (A.O.A.C.); 1970 was used.

\section{Procedure}

- $1.0 \mathrm{~g}$ of ground plant material was weighed into a $250 \mathrm{ml}$ conical flask.

- $4 \mathrm{ml}$ of perchloric acid $25 \mathrm{ml}$ of conc. $\mathrm{HNO}_{3}$ and $2 \mathrm{ml}$ of conc. $\mathrm{H}_{2} \mathrm{SO}_{4}$ were added to the sample in the conical flask.

- The contents were mixed and heated on a hot plate.

- The heating continued until dense white fumes appeared.
- $2 \mathrm{ml}$ of conc. $\mathrm{HNO}_{3}$ was added and heated for a minute.

- It was allowed to cool and $40 \mathrm{ml}$ of distilled water was added and boiled for half a minute on a hotplate.

- Cooled and filtered with whatman No. 42 filter paper into a $100 \mathrm{ml}$ Pyrex volumetric flask and made up to the mark with distilled water.

\section{Digestion of Sawdust Sample}

The procedure is the same with that for plant digestion.

\section{Instrumental Analysis}

The digested fish, water, plant and sawdust samples were analysed for Lead, Cadmium and Chromium using the atomic absorption spectrometer.

\section{Statistical Formulae}

1. $\operatorname{Mean}(\overline{\mathrm{X}})=\underline{\sum \mathrm{X}}$

$$
\mathrm{n}
$$

2. Standard deviation (S.d) $\sqrt{\frac{\sum|\mathrm{x}-\overline{\mathrm{x}}|^{2}}{\mathrm{n}-1}}$

3. Student t-test

$$
\mathrm{tcal}=\sqrt{\sqrt{\underline{\mathrm{X}}_{1}-\underline{\mathrm{X}}_{1}-\overline{\mathrm{X}}_{2}} \underline{\underline{\mathrm{s}}_{2} \underline{\underline{2}}}}
$$

Degree of freedom $=\mathrm{n}_{1}+\mathrm{n}_{2}-2$

$\mathrm{n}=$ number of samples,

$\mathrm{x}=$ mean for group samples,

$\mathrm{n}_{1}$ and $\mathrm{s}_{1}=$ number and standard deviation for samples.

\section{Results and Discussion}

In table1 Sawdust has the highest Lead and Chromium contents while water has the lowest Lead and Chromium contents. The plants had the highest Cadmium content while water had the lowest Cadmium content.

Table 2 shows that the differences between the levels of Lead and Cadmium in sawdust and fish are statistically significant. There is no significant difference between the level of Chromium in sawdust and fish studied.
The table 3 showed that sawdust has higher levels of Lead and Chromium in it than in the plant studied, while plant has higher level of cadmium than sawdust. However, there is no significant difference in the levels of lead, cadmium and chromium between sawdust and plant samples studied.

The table 4 above shows that the levels of lead, cadmium and chromium in the plant are higher than that in the fish studied. The different was not statistically significant. In fact, significant difference was found at $(\mathrm{P}<$ 
0.05) between the levels of cadmium and chromium in the plant and fish from the Lagos lagoon at Ebute-Meta.

Result in table 1 indicates a high degree of Lead and Chromium in sawdust when compared to the fish sample studied from the Lagos lagoon. Chromium was found in higher concentration in sawdust from the sawmill industries followed by Lead and cadmium. This indicates that those industrial activities such as sawmilling, log transportation and domestic waste disposal into the lagoon (found in the study area) increased the heavy metal intake by the fish studied.

\section{Conclusion}

From this work, it was found that activities such as sawmilling, log transportation and domestic waste disposal into the lagoon increases the levels of Cadmium, Lead and Chromium intake of fish samples studied indicating the risk of bioaccumulation and concentration.

\section{References}

Aina, O.M., Adetogun, A.C., Adedokun, M.O. and Onilude, M.A. 2006. Alternative Cooking Fuels From Sawmill Wastes. Farm Management Association of Nigeria. (FAMAN) Journal, 8(1): $45-49$.

Ajao, E.A 1990.The Influence of Domestic and Industrial Effluents on Populations of Sessile and Bentic Organisms in Lagos Lagoon. Ph.D Thesis. University of Ibadan. Nigeria. (Unpublished).

Burken, J.G. and Schnoor, J.L. 1996. Pytoremediation Plant Uptake of Artrazine and Role of Root Exudates. Journal of

Environmental Engineering 122 (9):58-63.

Chester, R. (1982). Regional Trends in the Distribution and sources of Aluminosilicates and Trace Metals in Recent North Atlantic Deep Sea Sediments. Bell. Inst. Geol. Basin d'Aquitance Bordeaux. 13(3): 25-35.

Cunningham, S.D., Anderson, T.A., Scwab, A.P and Hsu, F.C. 1996. Phytoremediation of Soils Contaminated with Organic Pollutants. Adv. Agron 55 (6):51-64.

Forestry Advisory Commission, Western State of Nigeria 1972. A Report on the Reviewof Assessment and Evaluation of Wood-Waste Owing to Bad Sawing and Poor Saw
The results of this study indicate that the concentration of Lead, Cadmium and Chromium in Oreochromis niloticus is within the lethal dose. The recommended range of these metals is: Lead $1.5-2.0 \mu \mathrm{g} / \mathrm{g}$ and 2.0 $3.0 \mu \mathrm{g} / \mathrm{g}$ for infant and adult respectively, Cadmium $0.4-0.5 \mu \mathrm{g} / \mathrm{g}$ for infant and 0.6$0.7 \mu \mathrm{g} / \mathrm{g}$ for adult and Chromium 0.01 $0.06 \mu \mathrm{g} / \mathrm{g}$ and $2.5-5.0 \mu \mathrm{g} / \mathrm{g}$ for children and adult respectively (Kochian, 1991).

\section{Recommendations}

- The sawdust and other sawmilling wastes can be used as raw material for several industries.

- Nigerian sawmillers and other prospective industrialists should be encouraged to establish industries to use these very cheap raw materials.

- Fishing should not be carried put in the Lagos lagoon at Ebute - Meta because of the lethal levels of the metals found in them.

Doctoring. Series 1. Quoted in Akachukwu, 2000.

Kochian, L.V. 1991. Mechanisms of Micronutrient Uptake and Translocation in Micronutrients in Agriculture. Ed. Mortvedt, J. J., Cox, F. R, Shuman, L.M., Welch, W. J. Madison, W.I. Soil Sci. Soc. America: 8(2): 2936

Lucas, E.B. 1975. Waste Tree Products in Nigeria: Their Causes, Extent and Characteristics. Nigerian Journal of Forestry 5(1\&2):24-30.

Ndiakwere, C.L. 1984. An Investigation of the Heavy Metal Content of Sediments andAlgae from The River Niger and Nigeria's Atlantic Coastal Waters. Environ. Poll. (B) 7(2):47-54. Okigbo, L. 1964. Sawmilling Industry in Nigeria. Federal Ministry of Information.

Raskin, I., Smith, R.D., and Salt, D.E. 1997. Phytoremediation of Metals Using Plants to Remove Pollutants from The Environment. Curr. Opin. Biotechnol. 8(2):21-26.

Sheppard, J.C. and Funk, W.H. 1975. Trees as Environmental Sensors, Monitoring LongTerm Heavy Metals Contamination of Spokane River, Idaho. Environ. Sci. Technol. 9(6):3842. 
Table 1: Summary table showing the mean and standard deviation of the results obtained for Lead, Cadmium and Chromium in sawdust, fish, plant and water samples.

\begin{tabular}{|l|l|l|l|l|}
\hline Metal & Sawdust $(\boldsymbol{\mu g} / \mathbf{g})$ & Fish $(\boldsymbol{\mu g} / \mathbf{g})$ & Plant $(\boldsymbol{\mu g} / \mathbf{g})$ & Water $(\mathbf{m g} / \mathbf{l})$ \\
\hline Lead & $43.0 \pm 0.99$ & $10.2 \pm 3.84$ & $29.2 \pm 22.06$ & $0.34 \pm 0.01$ \\
Cadmium & $33.6 \pm 3.54$ & $10.7 \pm 3.61$ & $37.0 \pm 3.96$ & $0.20 \pm 0.66$ \\
Chromium & $54.7 \pm 55.65$ & $4.7 \pm 1.07$ & $12.6 \pm 0.85$ & $0.17 \pm 0.21$ \\
\hline
\end{tabular}

All values are shown as mean \pm standard deviation.

Table 2: The Lead, Cadmium and Chromium concentration $(\mu \mathrm{g} / \mathrm{g})$ in sawdust and fish samples using student t-test.

\begin{tabular}{|l|l|l|l|l|l|}
\hline Metal & $\begin{array}{l}\text { Sawdust } \\
(\mu \mathrm{g} / \mathbf{g})\end{array}$ & Fish $(\mu \mathrm{g} / \mathbf{g})$ & T cal & T table & Remark \\
\hline Lead & $43.0 \pm 0.99$ & $10.2 \pm 3.84$ & 14.0 & 2.35 & $\mathrm{~S}$ \\
Cadmium & $33.6 \pm 3.55$ & $10.7 \pm 3.61$ & 7.02 & 2.35 & $\mathrm{~S}$ \\
Chromium & $54.7 \pm 55.65$ & $4.7 \pm 1.07$ & 1.27 & 2.35 & N.S \\
\hline
\end{tabular}

All values are shown as mean \pm standard deviation. S - Significant, N.S. - not significant

Table 3: The Lead, Cadmium and Chromium concentrations $(\mu \mathrm{g} / \mathrm{g})$ in sawdust and plant samples using student t-test.

\begin{tabular}{|l|l|l|l|l|l|}
\hline Metal & $\begin{array}{l}\text { Sawdust } \\
(\mu \mathrm{g} / \mathbf{g})\end{array}$ & Plant $(\mu \mathrm{g} / \mathbf{g})$ & T cal & T table & Remark \\
\hline Lead & $43.0 \pm 0.99$ & $29.2 \pm 22.06$ & 0.09 & 2.92 & N.S \\
Cadmium & $33.6 \pm 3.55$ & $37.0 \pm 3.96$ & 0.90 & 2.92 & N.S \\
Chromium & $54.7 \pm 55.65$ & $12.6 \pm 0.85$ & 1.07 & 2.92 & N.S \\
\hline
\end{tabular}

All values are shown as mean \pm standard deviation. N.S. - not significant

Table 4: The Lead, Cadmium and Chromium concentrations $(\mu \mathrm{g} / \mathrm{g})$ in plant and fish samples using student t-test.

\begin{tabular}{|l|l|l|l|l|l|}
\hline Metal & Plant $(\mu \mathrm{g} / \mathbf{g})$ & Fish $(\mu \mathrm{g} / \mathbf{g})$ & T cal & T table & Remark \\
\hline Lead & $29.2 \pm 22.06$ & $10.2 \pm 3.84$ & 1.21 & 2.35 & N.S \\
Cadmium & $37.0 \pm 3.96$ & $10.7 \pm 3.61$ & 7.54 & 2.35 & S \\
Chromium & $12.7 \pm 0.85$ & $4.7 \pm 1.07$ & 9.19 & 2.35 & S \\
\hline
\end{tabular}

All values are shown as mean \pm standard deviation. S - Significant, N.S. - not significant 